\title{
Neotypification of Fissidens arunii (Musci)
}

Maria Alida Bruggeman-Nannenga

Neotypification of Fissidens arunii (Musci). - Acta Mus. Siles. Sci. Natur., 68: 25-28, 2019.

\begin{abstract}
The poorly known Indian species Fissidens arunii is neotypified, described, figured and compared with other limbate, unipapillose species. Fissidens elimbatus is subsumed under F. crispulus, F. plumula under F. firmus and F. touwii under $F$. sedgwickii. Taxonomic changes: neotypification Fissidens arunii, F. crispulus Brid. ( $=$ F. elimbatus Broth. and $=F$. walkeri var. elimbatus (Broth.) Dixon), F. firmus (=F. plumula Mitt.). and F. sedgwickii Broth. \& Dixon (= Fissidens touwii Tad. Suzuki \& Z. Iwats.).
\end{abstract}

Key words: Asia, Fissidens arunii, Fissidens elimbatus, Fissidens crispulus, Fissidens plumula, Fissidens firmus, Fissidens touwii, Fissidens sedgwickii.

\section{Introduction}

When trying to identify a number of Indian specimens I came upon the name Fissidens arunii J. P. Srivast. \& Nork. It appeared quite a challenge to obtain a copy of the original description of this species. Since one of the authors, A. H. Norkett, used to work at BM I asked Len Ellis whether they had a copy in BM. It appeared that was not the case. Dr. Manju Nair put a request on Bryonet and received a scanned copy from Dr. Bill Buck in NY. The paper contains a description, illustration and an appointed holotype. Holotype: Mahableswar, Central India. On soil at the base of shaded rocks along wayside to Lingmala Fall, Oct. 1962. Leg. J. P. Srivastava Br. Sri. JPS 102. It further states that there is an isotype in BM. I tried to borrow the holotype from the institution where J.P. Srivastava has worked, viz. Chaudhary Mahadev Prasad Degree College, Allahabad. It appeared, however, that Srivastava's herbarium is not there. Via Bryonet I tried to contact Dr J. P. Srivastava and got a kind reaction from Dr S. N. Srivastava saying "I have tried to locate the holotype <for you> but failed. As far as I remember the specimens collected by Dr. J. P. Srivastava used to be in his personal herbarium-cum-library at his residence; and I presume that the said 'holotype' might be among these. I am not aware about the fate of his collections after his death since he had migrated to another city after his retirement nearly two decades ago". He kindly added the e-mail address of Dr J. P. Shrivasta's son who unfortunately did not answer my e-mail. So though it is unclear what has happened to J. P. Shrivasta's herbarium, it has to be feared that the type-specimen has gone lost. Then I asked for a loan of the isotype in BM. It appeared that BM has no specimen labelled "Mahableswar, Central India. On soil at the base of shaded rocks along wayside to Lingmala Fall, Oct. 1962. Leg. J. P. Srivastava Br. Sri. JPS 102", though there are several collections by Norkett named F. arunii. It seems therefore likely that the authors meant "paratypes" when they wrote that there is an isotype in BM. In other words, the species lacks a type and needs to be neotypified.

Fissidens arunii J.P. Srivast. \& Nork., Proc. Bot. Soc. Kanpur (India) 1: 55.1988 - Neotype nov.: INDIA, Maharashtra, Khandala, on hard earth beneath tree, sept 13 1970, Norkett 14266 (BM 001059776!). Additional representative specimens: INDIA, Alibat Ghat, 7 VII 1966, Norkett 10665 C (BM 001059779), Maharashtra State, Khandal, trees and banks near hotel, 24 VII 1966, Norkett 10773 (BM 001059777), Norkett 10831 (BM 001059782) and Maharashtra State, Borivli Park nr Bombay, 22 VIII 1966, Norkett 10855 (BM 001059779) and Norkett 14299 (BM 001059780) 


\section{Description of the neotype}

Growing in a loose mat, rhizoids basal, brown and smooth (mostly broken off); axillary nodules not differentiated; stems slightly browning in $\mathrm{KOH}$, frondose to shortly pinnate, $1.5-2.5 \times 1.0-2.5 \mathrm{~mm}$, unbranched; leaves mostly close, 3 - 7 pairs green, hardly crispate when dry, elliptico-lanceolate with an acute to acuteacuminate apex, $0.75-1.5 \times 0.2-0.4 \mathrm{~mm}, 3-4$ times as long as wide, limbate, margin crenulate to subentire where elimbate; limbidium present on all laminae of all well-developed leaves, reaching the leaf apex to ending below it, confluent at the apex of the vaginant laminae, reaching the insertions of the vaginant laminae or not, reaching the insertion of the dorsal lamina; on mid dorsal lamina $13-16 \mu \mathrm{m}$ wide, marginal or weakly and irregularly intramarginal, in mid vaginant laminae $40-68 \mu \mathrm{m}$ wide (including margin), intramarginal by 1 row of large cells; vaginant lamina $1 / 2-3 / 5$ leaf length, at the base about as wide as the stem, slightly open; dorsal lamina narrowed toward the insertion, reaching the insertion, not decurrent; costa stout, per- to long excurrent; mid dorsal laminal cells $10.0-12.0$ x 7.0-9.5 $\mu \mathrm{m}$, highly unipapillose, papillae cylindrical with blunt, often slightly clavate apex; mid vaginant laminal cells $7.5-10.5 \times 4.5-7.5 \mu \mathrm{m}$, each with a high, blunt cylindrical papilla; basal juxta-costal cells in vaginant laminal cells oblong, to $40 \mu \mathrm{m}$ long, smooth; no gemmae seen.

Fertile parts: perigonia and perichaetia terminal on separate plants in same mat; perigonial plants 0.4 $1.5 \mathrm{~mm}$ long, antheridia $\pm 150 \mu \mathrm{m}$ long; perichaetia terminal, perichaetial leaves $1.2-1.7 \mathrm{~mm}$ long; calyptra unknown. Sporophyte: seta $5-6 \mathrm{~mm}$ long, smooth, 1 per perichaetium; capsule inclined, $0.5-0.7$ x $0.35-0.45$ $\mathrm{mm}$, with ca. 32 columns quadratic-oblong exothecial cells with thickened corners; peristome scariosus type (only basal part seen), tooth base $\pm 41.5 \mu \mathrm{m}$ wide; operculum not seen; spores subglobose, $13.5-17.5 \mu \mathrm{m}$ diam., coarsely papillose.

Fissidens arunii is a variable species that is characterized by unipapillose cells, limbidia on all laminae, inclined capsules and per- to excurrent costae. The limbidia can be marginal or weakly and irregularly intramarginal on all laminae and can reach the apex or end well below it. Variations are seen in the papillae and the extension of the limbidium. The neotype has distinctive high, cylindrical papillae with a blunt, obtuse apex. Some other collections e.g. Norkett 14299 have lower or even partly lacking papillae. Likewise the extension of the limbidium varies from reaching the leaf apex in some collections (e.g. the neotype) to being restricted to the vaginant lamina and a few cells on the mid dorsal lamina as in Norkett 14299. Fissidens arunii can be confused other species with limbate leaves and mammilloseunipapillose laminal cells. Of these F. benitotanii Z. Iwats., K.T. Yong \& Tad. Suzuki from Malaysia is easily differentiated by its high, sharply unipapillose cells, F. raiatensis E.B. Bartram from the Society Islands differs by its almost smooth, weakly mammillose cells and limbidia that on the vaginant lamina are \pm marginal, but on the dorsal and apical lamina, irregularly intramarginal, often spurred and consist of short limbidial cells. Whereas the pantropical F. biformis Mitt. (characterized by limbidia reaching the apex and the insertion of the dorsal lamina) and the African Fissidens loennbergii P. de la Varde (with limbidia ending below the apex and above the leaf insertion) both differ from $F$. arunii in having axillary nodules. According to its protologue the Indian F. teniolatus Dixon \& P. de la Varde similarly has intramarginal limbidia, but this species has smooth cells.

\section{Discussion}

The holotype "Mahableswar, Central India. On soil at the base of shaded rocks along wayside to Lingmala Fall, Oct. 1962. Leg. J. P. Srivastava Br. Sri. JPS 102" could not be located and is probably lost. Though the protologue says that there is an isotype in BM no specimen of $F$. arunii -specimen collected by J. P. Srivastava could be found there. So the isotype could not be located either. There are, however, several $F$. arunii-collections in BM that were collected by the second author of the species A.H. Norkett. So, though not actually paratypes, they can be said to be original material. One of these, Norkett 14266, was annotated by Norkett as "Poor material first find at Mahableshwar in 1962. Then in 1966 further at Borivli and Khandale, but this [Norkett 14266] is the first very good, well developed material". Being thus highlighted by one of its authors Norkett 14266 is the obvious choice for the neotype. The plants agree well with the protologue in having unipapillose cells and limbidia on all laminae. 


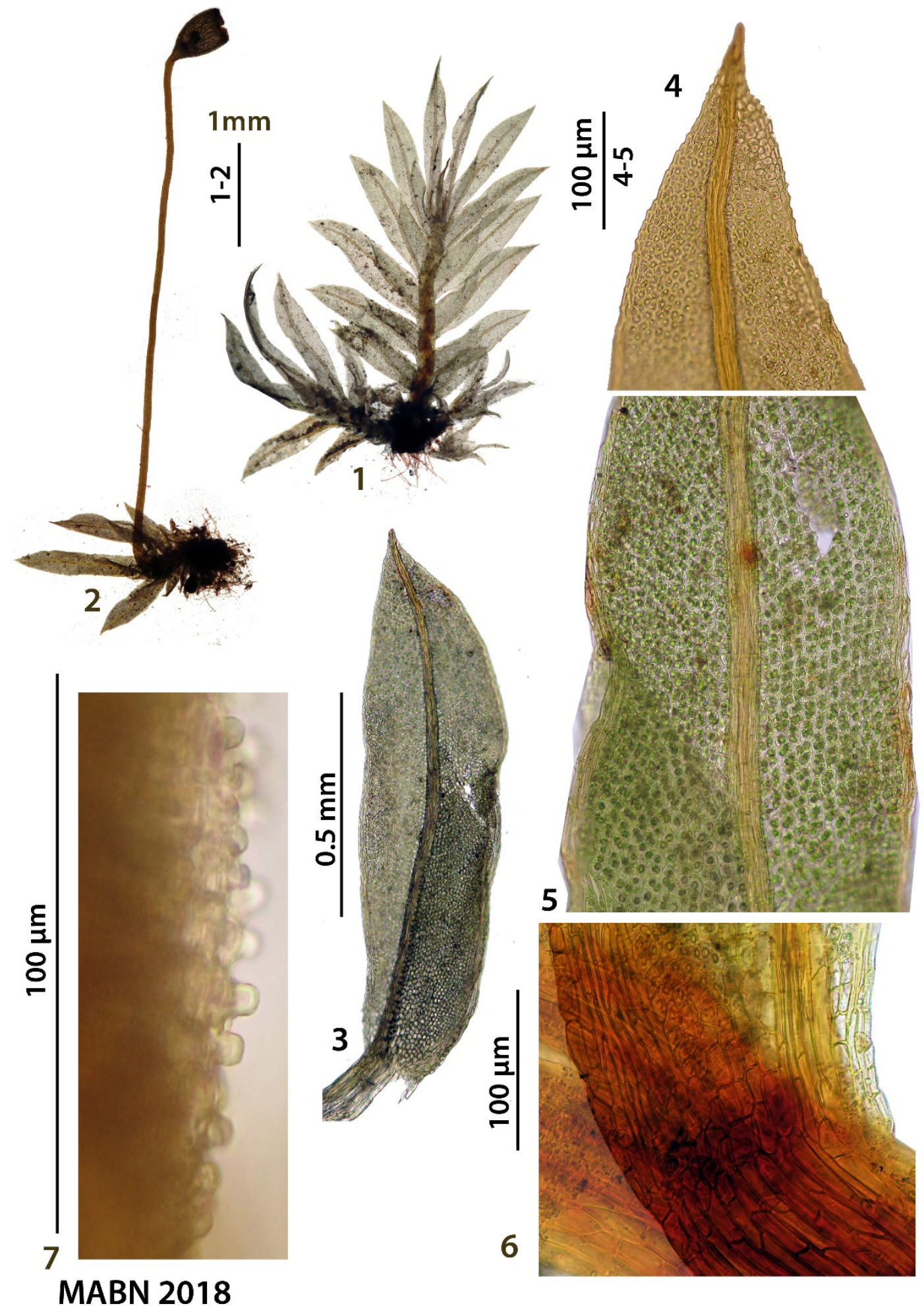

Fig 1: Fissidens arunii. 1 - cluster of perichaetial and perigonial stems, $\mathbf{2}$ - sporophytic stem, $\mathbf{3}$ - leaf, $\mathbf{4}$ - leaf apex (coloured by KOH 5\%), 5 - mid leaf, 6 - insertion leaf (coloured by KOH 5\%), 7 - papillae of vaginant lamina: 1 from Norkett 10773; 2, 5, 6, 7 from Norkett 14266 (neotype) and 3, 4, from Norkett 10665 . 


\section{New synonyms}

Fissidens crispulus Brid., Muscol. Recent. Suppl. 4: 187. 1819 [1818] - Lectotype (designated by Bruggeman-Nannenga, 1997): RÉUNION, [Insula Borbonica], Bory St Vincent, 1803 (B-hb Bridel!).

Fissidens elimbatus Broth., Rec. Bot. Surv. India 1(12): 316. 1899; Fissidens walkeri var. elimbatus (Broth.) Dixon, J. Indian Bot. 2: 177.1921 - Holotype: INDIA, Coorg, moist clay banks by roadside near Verajpet, XII 1897, Walker 151 (H-BR: H1633002!) - syn. nov.

Fissidens firmus Mitt., J. Proc. Linn. Soc., Bot., Suppl. 2: 139. 1859 - Type: SRI LANKA, [ins. Ceylon], in monte Adam's Peak, Gardner (label: Ceylon, Adam's Peak, March 1853, M. Thwaites 109) (holotype NY!).

Fissidens plumula Mitt., J. Linn. Soc., Bot.13: 325. 1873- Holotype: SRI LANKA, [Ins. Ceylon], Dr. Thwaites (label: Ceylon, Thwaites 134a) (NY01025920!] - syn. nov.

Fissidens sedgwickii Broth. \& Dixon, J. Bot. 48: 305. Tab. 507, f. 1.1910 - Type: INDIA, on stones near a fall known as Dhobis' Waterfall, Mahablehswar, Sedgwick 52 (lectotype nov.: $\mathrm{BM} !)$

Fissidens touwii Tad. Suzuki \& Z. Iwats., Hattoria 4: 43, f. 1, 2013 - Type: THAILAND, Udawn, sandstone massive Phu (Mt.) Luang, $17^{\circ} 25^{\prime}$ N, $101^{\circ} 25^{\prime}$ E. Touw 10788 (holotype CBG, isotypes: L!, MO) - syn. nov.

\section{References}

Bruggeman-Nannenga M.A. (1997): Notes on Fissidens VI. New Synonyms, new combinations and validation of some names. - Journal of the Hattori Botanical Laboratory 81: 155-173.

Author's address: M.A. Bruggeman-Nannenga, Griffensteijnseplein 23, NE-3703 BE Zeist, The Netherlands 